\title{
$\mathrm{RhD}$ 불일치 조혈모세포이식에서의 수혈 선택
}

김대원 · 김경희 · 서일혜 · 박필환 · 안정열 · 서자영

가천대학교 의과대학 길병원 진단검사의학과

\section{Transfusion in RhD Mismatch Hematopoietic Stem Cell Transplantation}

\author{
Daewon Kim, M.D., Kyung-Hee Kim, M.D., Yiel-Hea Seo, M.D., Pil-Whan Park, M.D., \\ Jeong-Yeal Ahn, M.D., Ja Young Seo, M.D.
}

Department of Laboratory Medicine, Gil Medical Center, Gachon University College of Medicine, Incheon, Korea

In some cases, hematopoietic stem cell transplants (HSCT) show differences in the D antigen. In previous studies, there have been few cases of de novo anti-D alloimmunization, and even rarer cases of serious side effects or the outcomes. De novo anti-D alloimmunization has been reported to occur more frequently in minor D mismatch than in major D mismatch. For the RhD type of blood components, RhD-negative type is recommended in transfusion in RhD mismatch HSCT without anti-D in donors and recipients. But in situations of insufficient RhD-negative blood supply, this study suggests that the RhD type of blood components depends on the patients' $\mathrm{RhD}$ type before transplantation, and it depends on the donors' RhD type after transplantation, and an RhD-positive platelet transfusion may be available. (Korean J Blood Transfus 2020;31:159-164)

Key words: Hematopoietic stem cell transplantation, D antigen, Alloimmunization, Mismatch, Transfusion support

조혈모세포이식 시 혈액형 항원 간 차이로 용 혈수혈반응이 나타날 수 있고, 이식 후에도 적혈 구 조혈이 지연될 수 있다. 용혈수혈반응은 $\mathrm{ABO}$ 혈액형 부적합에서 가장 흔하고, 다른 혈액형 차 이도 환자나 공여자의 항체 보유 여부에 따라 $\mathrm{ABO}$ 부적합만큼 주의를 요한다[1]. Rh 혈액형은 $\mathrm{ABO}$ 혈액형 다음으로 중요하고, $\mathrm{Rh}$ 혈액형군에 속하는 항원들로는 $\mathrm{D}, \mathrm{C}, \mathrm{E}, \mathrm{c}, \mathrm{e}$ 등 50 여 개 이상 있으며, 이 중 가장 면역원성이 강하고 임상적으
로 중요한 것은 D 항원이다. 항-D (anti-D)는 $\mathrm{ABO}$ 항체와 달리 자연적으로 발생하지 않으며 $\mathrm{D}$ 항 원 양성 적혈구에 노출된 후 면역반응이 필요하 다. 일단 감작이 되면, 환자는 평생 항-D가 존재 하며 사라지는 것은 드물다.

$\mathrm{RhD}$ 항원 보유 상태가 공여자와 수혜자 간에 다른 경우, D 항원 불일치(mismatch) 동종 조혈모 세포이식이라 한다[2]. "Minor"는 환자가 공여자 항체에 동종 항원이 있을 때, "Major"는 환자가

Received on July 9, 2020. Revised on July 14, 2020. Accepted on July 21, 2020

Correspondence to: Kyung-Hee Kim, M.D.

Department of Laboratory Medicine, Gil Medical Center, Gachon University College of Medicine, 21 Namdong-daero 774-gil, Namdong-gu, Incheon 21565, Korea

Tel: 82-32-460-3849, Fax: 82-32-460-3415, E-mail: khkim74@gilhospital.com, ORCID: https://orcid.org/0000-0002-6433-454X

() This is an Open Access article distributed under the terms of the Creative Commons Attribution Non-Commercial License (http://creativecommons.org/licenses/by-nc/4.0) which permits unrestricted non-commercial use, distribution, and reproduction in any medium, provided the original work is properly cited. Copyright (C) 2020 The Korean Society of Blood Transfusion 
공여자 항원에 동종 항체를 형성할 수 있을 때 쓰 인다. 드물게, $\mathrm{RhD}$ 음성 공여자나 수혜자가 동종 조혈모세포이식 전에 $\mathrm{D}$ 항원에 감작되어 항-D가 있는 경우가 있는데, 이는 D 항원 부적합(incompatibility) 동종 조혈모세포이식이라 한다[3].

$\mathrm{RhD}$ 불일치 조혈모세포이식 환자에게 수혈 시, 환자가 $\mathrm{RhD}$ 음성이고 공여자가 $\mathrm{RhD}$ 양성이 거나 그 반대인 경우 둘 다 $\mathrm{RhD}$ 음성 혈액제제를 수혈하고, $\mathrm{RhD}$ 양성 혈소판 수혈 시는 Rh 면역글 로불린을 주입하여 항-D 동종면역을 예방해야 함이 알려져 있다[4]. RhD 양성 혈소판 수혈 시 혈소판제제에 포함된 적혈구로 인한 항-D 동종 면역이 발생할 위험이 있어 $\mathrm{RhD}$ 음성 혈소판 수 혈을 선호하자는 의견도 있으나, 최근 태아신생 아용혈증후군이 발생할 수 있는 가임기 여성이 아니라면 Rh 면역글로불린 주입 없이 RhD 양성 혈소판 수혈을 하는 것에 대해 재평가를 하자는 의견이 제시되고 있다[1].

$\mathrm{RhD}$ 양성 환자에게 $\mathrm{RhD}$ 음성 공여자의 조혈 모세포이식 후에 완전 생착되면 $\mathrm{RhD}$ 음성 적혈 구를 생성하는데, 이 때 잔여 $\mathrm{RhD}$ 양성 적혈구가 혈류에 최소 4 개월간 존재하기 때문에 de novo 항-D 동종면역(de novo anti-D alloimmunization)이 발생할 수 있다. 또는 면역능이 있는 공여자의 B 림프구가 이식 후 환자 적혈구 항원에 반응하여 이로 인해 항체매개 용혈반응이 발생할 수도 있 는데, 이는 일과성림프구증후군(passenger lymphocyte syndrome)이다[5]. RhD 적혈구 항원에 대한 감작은 이식의 성패를 좌우하지 않더라도 직접항 글로불린검사에서 양성을 보인다든가 $\mathrm{RhD}$ 양성 적혈구를 파괴하여 용혈반응을 일으킬 수 있다 [4,6,7]. $\mathrm{RhD}$ 음성 환자에게 $\mathrm{RhD}$ 양성 공여자의 조혈모세포이식을 시행하는 경우 de novo 항-D가 발생하지 않을 수 있는데, 항-D를 생성할 수 있는 수혜자의 림프구가 골수제거 요법(myeloablative therapy)으로 파괴되기 때문인 것으로 추정된다. 실제로 이런 환자 및 공여자 군에서 항-D 동종면 역이 발생한 사례는 매우 드물게 보고된다[8]. $\mathrm{RhD}$ 음성 공여자가 $\mathrm{RhD}$ 양성 환자에게 이식한 경우(minor D mismatch) 9\%에서 항-D가 생성되 고, $\mathrm{RhD}$ 양성 공여자가 $\mathrm{RhD}$ 음성 환자에게 이식 한 경우(major D mismatch) 약 $1 \%$ 에서 항-D가 생 성되었으며, 두 가지 경우에서의 항-D 생성 차이 가 통계학적으로 유의한 것으로 알려져 있다[9].

$\mathrm{Rh}$ 면역글로불린 예방 요법이 이식 전 공여자 나 수혜자에서 항-D가 검출되는 $\mathrm{RhD}$ 부적합 조 혈모세포이식을 시행한 환자에서 이식 후 수혈 시 동종면역 예방을 위해 필요한지 논의가 제기 된 바 있다[10]. 한 연구에서는 $\mathrm{RhD}$ 음성 공여자 로부터 조혈모세포이식을 받은 $\mathrm{RhD}$ 양성 환자 1 예에서 이식 후 항-D가 검출되었지만, 임상적 및 진단검사적 용혈이 관찰되지 않았고[11], 다른 문 헌 또한, $\mathrm{RhD}$ 양성 수혜자가 $\mathrm{D}$ 항원에 감작된 $\mathrm{RhD}$ 음성 공여자로부터 이식 후 일과성림프구증 후군에 의한 용혈이 발생한 1 예가 있었으나, 항-D 생성 사례는 $\mathrm{RhD}$ 양성 공여자로부터 이식 받은 $\mathrm{RhD}$ 음성 수혜자들에게 더욱 많았는데 이들은 용혈 증상을 대부분 보이지 않아[12], 결론적으로 $\mathrm{Rh}$ 면역글로불린의 예방적 투여가 필수적인지는 확실하지 않다고 하였다[11].

이식 후 생존률은 독일에서 보고한 문헌에서 는 혈액형이 불일치한 환자가 $\mathrm{RhD}$ 혈액형 일치 인 환자보다 5년 생존률이 낮은 것으로 알려졌으 나[13], 반면에 미국에서 보고한 문헌에서는 최장 15 년까지 추적 결과 $\mathrm{RhD}$ 혈액형 일치 및 불일치 모두 생존율 차이가 없는 것으로 보고되었다[14]. 적혈구 항원 불일치 조혈모세포이식 환자의 수혈은 환자와 공여자의 면역혈액학적 특성을 모 두 고려해야 한다[15]. 공여자와 수혜자 모두 비 예기항체선별검사를 통해 $\mathrm{ABO}$ 항체 이외에 다 
른 항체도 존재 여부를 검사하고 이식 전후에 적 절한 혈액 제제를 제공하는 것이 중요한 점으로 강조된다. 이식한 이후에는 수혈 시 매번 수혈 전 검사를 통해 적혈구 항원 적합성에 대한 확인이 필요하고, 적혈구 항체 보유 여부에 대해 과거력 확인이 필요하다. 건강한 공여자 대다수는 공여 자-환자 간 혈청학적 교차시험이 환자 안전 증진 에 반드시 필요한 것은 아니지만[16] 개별 환자 별로 이식 계획 프로그램 수립 시 공여자-환자 조 합에게 적절한 검사 항목 지침을 정하는 것이 필 요하다.

$\mathrm{RhD}$ 혈액형 간 차이가 있는 조혈모세포이식에 서 수혈 선택은 $\mathrm{RhD}$ 음성 적혈구나 혈소판 및 혈 장 제제를 수혈하는 것이 가장 이상적이다. 다만, $\mathrm{RhD}$ 음성 혈액제제는 현실적으로 공급이 항상 충분하지는 않은 실정이다. 국내 수혈가이드라인 에서 $\mathrm{RhD}$ 음성 환자들에게 $\mathrm{RhD}$ 양성 혈액제제 수혈은, 적혈구의 경우 응급상황 시 인정되는 경 우가 있으며, 혈소판이나 신선동결혈장과 동결침 전제제는 가능하며, $\mathrm{Rh}$ 면역글로불린 투여를 권 장하거나 고려할 것으로 지침한다[17]. $\mathrm{RhD}$ 양성 환자가 $\mathrm{RhD}$ 음성 공여자로부터 조혈모세포이식
후 완전 생착되면 $\mathrm{RhD}$ 음성 적혈구를 생성하지 만, 잔여 $\mathrm{RhD}$ 양성 적혈구의 혈류 내 잔류로 인 해 de novo 항-D가 생성된 경우에는 $\mathrm{RhD}$ 음성 적 혈구제제 수혈이 필요하다. 반대로 면역억제 상 태인 $\mathrm{RhD}$ 음성 환자가 $\mathrm{RhD}$ 양성 공여자로부터 조혈모세포이식을 받은 경우는 de novo 항-D가 발생하지 않을 수 있으므로[8] RhD 양성 적혈구 제제 수혈을 고려할 수 있다고 생각한다. 혈소판 자체에는 $\mathrm{RhD}$ 항원이 표현되지 않지만, 혈소판 제제에 포함된 미량의 적혈구로 인한 감작 가능 성이 존재한다. 일반적인 경우에도 $\mathrm{RhD}$ 음성 환 자에게 $\mathrm{RhD}$ 양성 혈소판을 수혈한 경우 항-D 동 종면역 발생률은 1 7\% 이내로 알려져 있으며 특별한 부작용이 없는 경우가 많았다[18-20]. 혈 장제제의 경우에도 신선동결혈장 제제 내 포함된 적혈구로 인한 것으로 여겨지는 항-D 동종면역 에 대한 보고가 소수 존재하고, $\mathrm{Rh}$ 면역글로불린 투여를 가임기 여성, 이전 감작 가능성이 있는 경 우, 혈장교환술 등 대량 수혈이 예상되는 경우, 장기적인 수혈가능성이 있는 경우 등 일부 위험 성이 높은 상황에서는 고려할 필요성을 언급한 바도 있다[21]. 조혈모세포이식 시 혈장제제 수혈

Table 1. Transfusion selections and de novo anti-D alloimmunization in D antigen mismatched HSCT

\begin{tabular}{|c|c|c|c|c|c|c|c|c|c|}
\hline \multirow{3}{*}{ Year } & \multicolumn{4}{|c|}{ Minor D mismatch } & \multicolumn{3}{|c|}{ Major D mismatch } & \multirow{3}{*}{$\begin{array}{c}\text { Total } \\
\text { incidence }\end{array}$} & \multirow{3}{*}{$\begin{array}{c}\text { Country } \\
{[\text { References }]}\end{array}$} \\
\hline & Before HSCT & \multicolumn{2}{|c|}{ After HSCT } & \multirow{2}{*}{-Incidence } & Before HSCT & After HSCT & \multirow{2}{*}{ - Incidence } & & \\
\hline & RBC Platelet & $\mathrm{RBC}$ & Platelet & & RBC Platelet & $\mathrm{RBC}$ Platelet & & & \\
\hline 2006 & $\begin{array}{c}\text { Both } \\
\text { (D poth } \\
79 \%) \\
(\mathrm{D} \text { pos, } \\
81 \%)\end{array}$ & $\begin{array}{l}\text { D neg } \\
\text { only }\end{array}$ & $\begin{array}{c}\text { Both } \\
\text { (D pos, } \\
83 \% \text { ) }\end{array}$ & $\begin{array}{c}0 \% \\
(0 / 15)\end{array}$ & $\begin{array}{c}\text { D neg Both } \\
\text { only (D pos, } \\
79 \%)\end{array}$ & $\begin{array}{l}\text { Both Both } \\
\text { (D pos, (D pos, } \\
8 \%) \quad 85 \%)\end{array}$ & $\begin{array}{c}0 \% \\
(0 / 15)\end{array}$ & $\begin{array}{c}0 \% \\
(0 / 30)\end{array}$ & Spain [8] \\
\hline 2008 & $\begin{array}{c}\text { Not } \\
\text { reported }\end{array}$ & $\begin{array}{l}\text { D neg } \\
\text { only }\end{array}$ & Both & $\begin{array}{l}11 \% \\
(3 / 27)\end{array}$ & $\begin{array}{c}\text { Not } \\
\text { reported }\end{array}$ & $\begin{array}{l}\text { D neg } \\
\text { only }\end{array}$ & $\begin{array}{c}0 \% \\
(0 / 18)\end{array}$ & $\begin{array}{c}7 \% \\
(3 / 45)\end{array}$ & USA [14] \\
\hline 2012 & $\begin{array}{c}\mathrm{D} \text { pos } \\
\text { preference }\end{array}$ & $\begin{array}{c}\mathrm{D} \\
\text { prefe }\end{array}$ & $\begin{array}{l}\text { neg } \\
\text { rence }\end{array}$ & $\begin{array}{l}10 \% \\
(2 / 21)\end{array}$ & $\begin{array}{l}\mathrm{D} \text { neg } \\
\text { preference }\end{array}$ & $\begin{array}{c}\mathrm{D} \text { pos } \\
\text { preference }\end{array}$ & $\begin{array}{c}0 \% \\
(0 / 19)\end{array}$ & $\begin{array}{c}5 \% \\
(2 / 40)\end{array}$ & Austria [22] \\
\hline
\end{tabular}

Abbreviations: HSCT, hematopoietic stem cell transplantation; neg, negative; pos, positive. 
에 관한 언급은 혈소판제제에 비해 없는 편이나, 항-D 동종면역 위험도는 혈소판 제제와 마찬가 지로 낮을 것으로 생각된다.

기존 문헌들에서 minor D mismatch 및 major D mismatch 조혈모세포이식에서 수혈 정책과 $\mathrm{de}$ novo 항-D 동종면역 발생률은 Table 1 과 같다. $\mathrm{RhD}$ 음성 공여자로부터 이식 받는 $\mathrm{RhD}$ 양성 환 자의 경우(minor D mismatch) 이식 전 적혈구와 혈소판을 RhD 양성 및 음성 두 가지로 수혈 받았 고, 이식 후에는 적혈구는 공여자 혈액형과 같은 $\mathrm{RhD}$ 음성으로만, 혈소판은 $\mathrm{RhD}$ 양성 및 음성 두 가지로 수혈받았다. RhD 양성 공여자로부터 이 식받는 $\mathrm{RhD}$ 음성 환자의 경우(major D mismatch) 이식 전 적혈구는 환자 혈액형과 같은 $\mathrm{RhD}$ 음성 으로만, 혈소판은 RhD 양성 및 음성으로 수혈 받 았고, 이식 후에는 적혈구와 혈소판 모두 $\mathrm{RhD}$ 양 성 및 음성 혈 액형으로 수혈하였다. 이 문헌에서 항-D 동종면역이 확인된 환자는 없었다[8]. 다른 문헌에서는 이식 후에는 두 가지 $\mathrm{RhD}$ 불일치 경 우 모두에서 적혈구는 RhD 음성 제제를 수혈하 였고, 혈소판은 $\mathrm{RhD}$ 음성을 우선적으로 수혈하 였으나 공급 부족 시 $\mathrm{RhD}$ 양성 혈소판제제로 수 혈하였다. 해당 연구에서는 minor D mismatch 이 식 사례 27 명 중 3 명에서 항-D 동종면역이 관찰 되었다[14]. 또 다른 문헌에서는 $\mathrm{RhD}$ 불일치 조
혈모세포이식 환자의 수혈 정책에 대해서 이식 1 일 전까지는 환자의 $\mathrm{RhD}$ 혈액형으로 적혈구 및 혈소판제제를 수혈하고 이식 당일부터는 공여자 의 $\mathrm{RhD}$ 혈액형으로 적혈구 및 혈소판제제를 선 택하며, 모든 혈액제제는 백혈구제거필터 및 방 사선 조사하여 수혈하였다. 항-D 동종면역이 관 찰된 환자는 minor D mismatch 이식 사례 21 명 중 2명이었다[22]. 그 외 다른 문헌에서는 major D mismatch 이식 사례 43 명 중 2 명에서 $\mathrm{RhD}$ 양성 혈소판 수혈 뒤 주입된 $\mathrm{Rh}$ 면역글로불린으로 인 한 일시적인 항-D의 검출이 있었으나, de novo 항 -D 동종면역으로 판정할 수 있는 사례는 major와 minor D mismatch 모두에서 관찰되지 않았다[2].

De novo 항-D 동종면역이 발생하지 않은 RhD 불일치 조혈모세포이식 환자 수혈에서 $\mathrm{RhD}$ 선택 에 대해 Table 2와 같이 제시하였다. 조혈모세포 이식 환자는 골수제거 요법 등으로 인해 면역억 제 상태인 경우가 대다수이며, 이는 항-D 생성이 잘 일어나지 않는 요인으로 작용한다. $\mathrm{RhD}$ 음성 혈액 제제 보유량이 충분하다면 $\mathrm{RhD}$ 음성 혈액 제제를 이식 전후 모두 수혈할 수 있겠으나, 현실 적으로 $\mathrm{RhD}$ 음성 혈액제제는 부족한 경우가 종 종 있다. 이런 경우 적혈구와 혈소판 및 혈장제제 모두 $\mathrm{RhD}$ 불일치 이식 $\mathrm{D}-1$ 일까지는 환자의 $\mathrm{RhD}$ 혈액형에 따라 수혈하고, 이식 후에는 공여 받은

Table 2. Suggestion of blood type selection in RhD mismatch HSCT without anti-D in donors and recipients in the situation of insufficient RhD-negative blood supply

\begin{tabular}{|c|c|c|c|c|c|c|}
\hline \multirow[b]{2}{*}{ Difference in $\mathrm{RhD}$ type } & \multirow[b]{2}{*}{ Donor } & \multirow[b]{2}{*}{ Recipient } & \multicolumn{2}{|c|}{ Before HSCT } & \multicolumn{2}{|r|}{ After HSCT } \\
\hline & & & $\mathrm{RBC}$ & $\begin{array}{c}\text { Platelet and } \\
\text { plasma components }\end{array}$ & $\mathrm{RBC}$ & $\begin{array}{c}\text { Platelet and } \\
\text { plasma components }\end{array}$ \\
\hline Minor mismatch & $\mathrm{D}-$ & $\mathrm{D}+$ & $\mathrm{D}+$ & $\mathrm{D}+$ & $\mathrm{D}-$ & $\mathrm{D}-/ \mathrm{D}+$ \\
\hline Major mismatch & $\mathrm{D}+$ & $\mathrm{D}-$ & $\mathrm{D}-$ & $\mathrm{D}-/ \mathrm{D}+$ & $\mathrm{D}+$ & $\mathrm{D}+$ \\
\hline
\end{tabular}

Abbreviation: HSCT, hematopoietic stem cell transplantation. 
$\mathrm{RhD}$ 혈액형에 따라 수혈한다. 특히 혈소판제제 의 경우 공급 부족이 발생하기 쉬우므로, 비록 $\mathrm{RhD}$ 음성 제제가 선호되는 $\mathrm{RhD}$ 음성 환자의 이 식 전 수혈이나 $\mathrm{RhD}$ 음성 공여를 받은 후에라도, 공급 상황에 따라서는 $\mathrm{RhD}$ 양성 혈소판을 수혈 할 수 있으며, 추후 임신 가능성이 있거나 대량 수혈일 경우 $\mathrm{Rh}$ 면역글로불린 투여를 권장한다.

\section{References}

1. Fung MK, Grossman BJ, Hillyer CD, Westhoff CM. Technical manual. 18th ed. Bethesda: American Association of Blood Banks, 2014: 633-4

2. Chan JY, Tokessy M, Saidenberg E, Giulivi A, Tay J, Allan DS. Rh D alloimmunization in allogeneic HSCT. Bone Marrow Transplant 2013; 48:459-60

3. Berkman EM, Caplan SN. Engraftment of RHpositive marrow in a recipient with $\mathrm{RH}$ antibody. Transplant Proc 1977;9(1 Suppl 1):215-8

4. Han K, Park K, Song E. Transfusion medicine. 4th ed. Seoul: Medical Book Publisher, 2014: 210

5. Taniguchi K, Yoshihara S, Maruya E, Ikegame K, Kaida K, Hayashi K, et al. Donor-derived HLA antibody production in patients undergoing SCT from HLA antibody-positive donors. Bone Marrow Transplant 2012;47:1338-42

6. Girelli G, Arcese W, Bianchi A, Mauro FR, Malagnino F, Adorno G, et al. Hemolysis in Rh-negative female recipient after Rh-incompatible bone marrow transplantation for chronic myeloid leukemia. Haematologica 1986;71:46-9

7. Lasky LC, Warkentin PI, Kersey JH, Ramsay NK, McGlave PB, McCullough J. Hemotherapy in patients undergoing blood group incompatible bone marrow transplantation. Transfusion
1983;23:277-85

8. Cid J, Lozano M, Fernández-Avilés F, Carreras E, Pereira A, Mazzara R, et al. Anti-D alloimmunization after D-mismatched allogeneic hematopoietic stem cell transplantation in patients with hematologic diseases. Transfusion 2006; 46:169-73

9. Cid J, Lozano M, Klein HG, Flegel WA. Matching for the D antigen in haematopoietic progenitor cell transplantation: definition and clinical outcomes. Blood Transfus 2014;12: 301-6

10. Heim MU, Schleuning M, Eckstein R, Huhn D, Siegert W, Clemm C, et al. Rh antibodies against the pretransplant red cells following Rh-incompatible bone marrow transplantation. Transfusion 1988;28:272-5

11. de La Rubia J, Arriaga F, Andreu R, Sanz G, Jiménez C, Vicente A, et al. Development of non-ABO RBC alloantibodies in patients undergoing allogeneic HPC transplantation. Is ABO incompatibility a predisposing factor? Transfusion 2001;41:106-10

12. Hows J, Beddow K, Gordon-Smith E, Branch DR, Spruce W, Sniecinski I, et al. Donorderived red blood cell antibodies and immune hemolysis after allogeneic bone marrow transplantation. Blood 1986;67:177-81

13. Erker CG, Steins MB, Fischer RJ, Kienast J, Berdel WE, Sibrowski W, et al. The influence of blood group differences in allogeneic hematopoietic peripheral blood progenitor cell transplantation. Transfusion 2005;45:1382-90

14. Wirk B, Klumpp TR, Ulicny J, Herman JH, Gajewski JL, Martin ME, et al. Lack of effect of donor-recipient $\mathrm{Rh}$ mismatch on outcomes after allogeneic hematopoietic stem cell transplantation. Transfusion 2008;48:163-8

15. Lapierre V, Kuentz M, Tiberghien P. Allogeneic peripheral blood hematopoietic stem cell 
transplantation: guidelines for red blood cell immuno-hematological assessment and transfusion practice. Société Française de Greffe de Moelle. Bone Marrow Transplant 2000;25:507-12

16. Heddle NM, O'Hoski P, Singer J, McBride JA, Ali MA, Kelton JG. A prospective study to determine the safety of omitting the antiglobulin crossmatch from pretransfusion testing. Br J Haematol 1992;81:579-84

17. Korean Society of Blood Transfusion. Transfusion guideline. Cheongju: Korea Centers for Disease Control \& Prevention, Korean Society of Blood Transfusion; 2016 Aug. Report No.: 11-1352159-000534-01

18. Cid J, Lozano M, Ziman A, West KA, O'Brien $\mathrm{KL}$, Murphy MF, et al. Low frequency of anti-D alloimmunization following $\mathrm{D}+$ platelet transfusion: the Anti-D Alloimmunization after
D-incompatible Platelet Transfusions (ADAPT) study. Br J Haematol 2015;168:598-603

19. Cid J, Harm SK, Yazer MH. Platelet transfusion - the art and science of compromise. Transfus Med Hemother 2013;40:160-71

20. Asfour M, Narvios A, Lichtiger B. Transfusion of RhD-incompatible blood components in $\mathrm{RhD}$-negative blood marrow transplant recipients. MedGenMed 2004;6:22

21. Kim MS, Kim H, Ko DH, Hwang SH, Oh HB. $\mathrm{RhD}$ immunoprophylaxis in plasma transfusion. Korean J Blood Transfus 2018;29:194-7

22. Worel N, Böhm A, Rabitsch W, Leitner G, Mitterbauer M, Kalhs P, et al. Frequency and prognostic value of $\mathrm{D}$ alloantibodies after D-mismatched allogeneic hematopoietic stem cell transplantation after reduced-intensity conditioning. Transfusion 2012;52:1348-53 